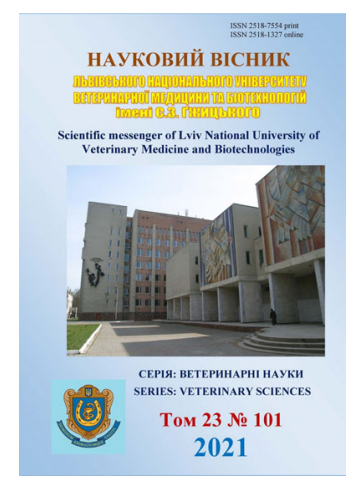

Науковий вісник Львівського національного університету ветеринарної медицини та біотехнологій імені С.3. Гжицького. Серія: Ветеринарні науки

\author{
Scientific Messenger of Lviv National University \\ of Veterinary Medicine and Biotechnologies. \\ Series: Veterinary sciences
}

doi: 10.32718/nvlvet10112

https://nvlvet.com.ua/index.php/journal

UDC 619.579 .62

\title{
The activity of the disinfectant "Enzidez" against bacteria in biofilms
}

\author{
V. Kozhyn ${ }^{1}$, M. Kukhtyn ${ }^{2}$, V. Horiuk ${ }^{1}$, O. Vichko², Y. Kryzhanivsky ${ }^{3}$ \\ ${ }^{1}$ State Agrarian and Engineering University in Podilya, Kamianets-Podilskyi, Ukraine \\ ${ }^{2}$ Ternopil Ivan Puluj National Technical University, Ternopil, Ukraine \\ ${ }^{3}$ Research Station of the Institute of Veterinary Medicine of NAAS, Ternopil, Ukraine
}

Article info

Received 14.01.2021

Received in revised form 15.02.2021

Accepted 16.02.2021

State Agrarian and Engineering University in Podilya, Schevchenko Str., 13, KamianetsPodilskyi, Khmelnytskyi region, 32300, Ukraine.

Tel.: +38-097-661-79-64

E-mail: goruky@ukr.net

Ternopil Ivan Puluj National Technical University, Department of Food Technologies, Ruska Str., 56, Ternopil, 46001 Ukraine.

Research Station of the Institute of Veterinary Medicine of NAAS, Troleibusna Str., 12, Ternopil, 46027, Ukraine.
Kozhyn, V., Kukhtyn, M., Horiuk, V., Vichko, O., \& Kryzhanivsky, Y. (2021). The activity of the disinfectant "Enzidez" against bacteria in biofilms. Scientific Messenger of Lviv National University of Veterinary Medicine and Biotechnologies. Series: Veterinary sciences, 23(101), 6774. doi: $10.32718 /$ nvlvet10112

Currently, the pharmaceutical industry is constantly working on the creation of ideal disinfectants that would have a wide spectrum of antimicrobial action in minimal concentrations, did not result in the formation of stability in bacteria, were not toxic, not corrosive, not allergenic, cheap. The purpose of the work was to investigate the activity of the "Enzidesis" disidissance to influence microbial biofilms in vitro conditions for various sampling parameters. The density of microbial biofilms and the effects of disinfectants were determined on sterile stainless steel plates, which were placed in a Petri dish. For this purpose, biofilms were grown on plates, washed out biofilms from planktonic cells, acted as a disguise for a certain concentration and for a period of 5-30 minutes, fixed and painted biofilms and determined the optical density of the flushing solution from biofilms spectrometrically. It has been established that the disinfectant "Enzidesis" destroys the biofilms taken in the experiment of museum test cultures $S$. aureus, E. coli and $P$. aeruginosa. In particular, for the influence of the lowest concentration in experiment, $0.075 \%$ optical density of washing solutions from $S$. aureus biofilmes decreased by 2.6 times, E. coli and P. aeruginosa biofilm in 2.9 times, respectively, comparing with biofilms after treatment with water. Under the actions of such a concentration of the "Enzidesis" means, the biofilm though significantly degraded, but they were still a medium density, more than 0.5 units. Increasing the concentration of a means of $0.075 \%$ to $0.5 \%$ contributed to the intensity of degradation of test-cultures, an average of 3.0 times $(P<0.05)$ and they became a weak density (0.24-0.20 s). Increasing the concentration of the "Enzidesis" means up to $1.0 \%$ or more, did not significantly destroy the matrix of the biofilm of microorganisms, since the optical density of the washing solutions was as in control. In determining the influence of the temperature of the working solutions of the "Enzidosis" means on its film-building activity, it has been found that with an increase in the disinfection agent "Enzidesis" with +20 to $+60^{\circ} \mathrm{C}$ there is an increase in the degradation of the biofilm formed S. aureus, E. coli and P. aeruginosa. Dezilities can be effectively used in $0.5 \%$ concentration at room temperature of solutions. When substantiating the exposure time of the "Enzidesis" exhibition time, it has been found that to remove the $S$. aureus, E. coli and $P$. aeruginosa $0.5 \%$ means at a solution temperature of $+20 \pm 1{ }^{\circ} \mathrm{C}$, it is necessary that the action time is from 15 to 30 minutes.

Key words: enzidesis, biofilm density, biofilm degradation, product efficiency.

\section{Активність дезінфікуючого засобу “Ензидез” щодо бактерій у біоплівках}

\author{
В. А. Кожин ${ }^{1}$, М. Д. Кухтин ${ }^{2}$, В. В. Горюк ${ }^{1}$, О. І. Вічко ${ }^{2}$, Я. Й. Крижанівський ${ }^{3}$ \\ ${ }^{1}$ Подільський державний аграрно-технічний університет, м. Кам'янець-Подільський, Украӥна \\ ${ }^{2}$ Тернопільський національний технічний університет імені І. Пулюя, м. Тернопіль, Украӥна \\ ${ }^{3}$ Тернопільська дослідна станц̧ія Інституту ветеринарної медицини НААН, м. Тернопіль, Україна
}


У даний час фармацевтична галузь постійно праџює над створенням ідеальних дезінфікуючих засобів, які б володіли иироким спектром антимікробної дї у мінімальних концентраціях, не спричиняли формування стійкості у бактерій, були не токсичними, не корозійними, не алергенними, дешевими. Метою роботи було дослідити активність дезіфікуючого засобу “Ензидез” шодо впливу на мікробні біоплівки в умовах іп vitro за різних параметрів застосування. Щільність мікробних біоплівок та вплив на них дезінфікуючого засобу визначали на стерильних пластинках з нержавіючої сталі, які помішали в чашки Петрі. Для иього вирошували біоплівки на пластинках, відмивали біоплівки від планктонних клітин, діяли деззасобом за певної концентрації та протягом часу 5-30 хв, фіксували та фарбували біоплівки $і$ визначали оптичну густину змивного розчину з біоплівок спектрометрично. Встановлено, що дезінфікуючий засіб “Ензидез” руйнує біоплівки взятих у дослід музейних тест-культур S. аитеия, E. солі $i$ P. aeruginosa. Зокрема, за впливу найнижчої взятої у дослід концентрації 0,075 \% оптична густина промивних розчинів з біоплівок S. aureus зменшилася в 2,6 раза, біоплівок E. coli i P. aеruginosa в 2,9 раза, відповідно, порівнюючи з біоплівками після обробки водою. За дії такої концентрації засобу “Ензидез” біоплівки хоч значно деградували, проте вони ще були середньої щзільності, більще 0,5 од. Підвищення концентрації засобу з 0,075\% до 0,5\% сприяло інтенсивності деградації біоплівки тест-культур, в середньому в 3,0 раза $(P<0,05)$ і вони ставали слабкої шільності $(0,24$ - 0,20 од). Підвищення концентрації засобу “Ензидез” до 1,0\% $і$ більще, не суттєво руйнувало матрикс біоплівки мікроорганізмів, так як оптична густина промивних розчинів була як у контролі. При визначенні впливу температури робочих розчинів засобу “Ензидез” на його плівкоруйнуючу активність, встановлено, ичо із підвищенням температури дезінфікуючого засобу “Ензидез” з +20 до $+60{ }^{\circ} \mathrm{C}$ відбувається збільшення деградації біоплівок сформованих S. aureus, E. coli i P. aeruginosa. Деззасіб можна ефективно використовувати в 0,5 \% концентрації за кімнатної температури розчинів. При обтрунтуванні часу експозииї деззасобу “Ензидез” виявлено, щуо для видалення біоплівок S. аигеиs, E. солі i P. аегиginosa 0,5\% засобом за температури розчинів $+20 \pm 1{ }^{\circ} \mathrm{C} \mathrm{необхідно,} \mathrm{щзоб} \mathrm{час} \mathrm{дії} \mathrm{становив} \mathrm{від} 15$ до 30 хв.

Kеу words: Ензидез, щ⿻ільність біоплівки, деградація біоплівки, ефективність засобу.

\section{Вступ}

У даний час фармацевтична галузь постійно працює над створенням ідеальних дезінфікуючих засобів, які б володіли широким спектром антимікробної дії у мінімальних концентраціях, не спричиняли формування стійкості у бактерій, були не токсичними, не корозійними, не алергенними, дешевими, тощо (Palii et al., 2020; Kovalenko et al., 2020). Для цього використовуються та поєднаються між собою дезінфікуючі субстанції із різних груп, дія яких направлена на пригнічення активності різних ферментних систем бактеріальної клітини та руйнування іiі структурних елементів (Augustin et al., 2004; Kovalenko et al., 2018). Проте, незважаючи на достатньо велику кількість дезінфікуючих засобів на ринку, ідеального - препарату не існує, так як мікроорганізми доволі швидко адаптуються до нових антибактеріальних субстанцій (Berhilevych et al., 2017; Horiuk et al., 2018).

Крім того, стійкість у бактерій до біоцидів може бути пов'язана із перебуванням їх у біоплівці (Ноquе et al., 2015; Kukhtyn et al., 2019). Сучасний узагальнений термін “біоплівка" використовується для визначення сукупності бактерій і продуктів їх метаболізму на межі поділу фаз - твердої і рідкої, прикріплених до поверхні у водному або водонасиченому середовищі (Costerton et al., 2003). Сьогодні більшістю вчених визнано, що значна кількість мікроорганізмів у природних і штучно створених середовищах існує у вигляді структурованих, прикріплених до поверхні угрупувань - біоплівок (Davin-Regli et al., 2012; Kukhtyn et al., 2017). Бактерії у біоплівці оточені власним продукуючим матриксом, який складається 3 полісахаридів, протеїнів, уранової кислоти та гумінової речовини (Costerton et al., 2003). Саме завдяки матриксу багато протимікробних засобів не проникають у біоплівку, який діє як бар'єр, що захищає бактеріальні клітини всередині (Lequette et al., 2010). Перебування бактерій у біоплівці створює серйозні проблеми з інфікуванням різних поверхонь у медицині, ветеринарії та харчовій промисловості (Ноque et al., 2015; Kukhtyn et al., 2019). Бактерії у біоплівках, набагато складніше знищити антимікробними препаратами, що потенційно може призвести до накопичення i поширення небезпечних збудників. Тому, постійно проводяться зусилля щодо поліпшення роботи існуючих дезінфікуючих засобів або розробки нових для впливу на мікроорганізми у біоплівковому стані. Нами розроблено новий дезінфікуючий засіб "Ензидез” (діючі речовини: полігексаметиленбігуанідину гідрохлориду, четвертинні амонієві сполуки та протеолітичні і амілолітичні ензими) для боротьби 3 бактеріями, які перебувають у складі біоплівки.

Отже, враховуючи роль матриксу у захисті мікробних клітин від дії біоцидів визначення активності нових деззасобів відносно деградації біоплівки $є$ важливою передумовою оцінки їх ефективності перед впровадженням у практику.

Метою роботи було дослідити активність дезіфікуючого засобу “Ензидез” щодо впливу на мікробні біоплівки в умовах in vitro за різних параметрів застосування.

\section{Матеріал і методи досліджень}

У дослідах використали музейні штами тесткультур E. coli (055К59 №3912/41), S. aureus (АТCC 25923) і P. aeruginosa (27/99). Пластинки 3 нержавіючої сталі марки AISI 321 розміром $30 \times 30$ мм на яких вирощували біоплівки.

Щільність мікробних біоплівок та вплив на них дезінфікуючого засобу визначали згідно методичних рекомендацій (Kukhtyn et al., 2020). Коротко: вирощували біоплівки тест-культур бактерій на стерильних пластинах з нержавіючої сталі в чашках Петрі протягом 24 год в мясопептонному бульйоні з $1 \%$ концентрацією глюкози. Потім промивали тричі (трьохразово) пластинки з біоплівками стерильним фосфатним буфером для видалення планктонних клітин, і висушували пластини. Вносили у чашки Петрі з пластинами дезінфікуючий засіб (за різної концентрації та температури розчинів) та витримували протягом певного часу, залежно від мети досліду. Витягували пластини, промивали фосфатним буфером і фіксували 
біоплівки $96^{\circ}$ етиловим спиртом упродовж 10 хвилин. Потім фарбували біоплівки розчином кристалічного фіолетового 10 хвилин. Після цього знову тричі (трьохразово) промивали пластинки 3 біоплівками фосфатним буфером для видалення залишків фарби. Потім у чашку Петрі з пластинкою вносили 5,0 $\mathrm{cm}^{3}$ $96^{\circ}$ етилового спирту і залишали на 20-30 хв, періодично струшуючи. Вимірювали оптичну густину спиртового розчину спектрофотометрично за умови довжини хвилі 570 нМ. За оптичної густини промивного розчину до 0,5 од. щільність сформованих біоплівок вважали низькою, від 0,5 до 1,0 од. - середньою та при густині розчину більше 1,0 од. щільність сформованої біоплівки вважали високою (Kukhtyn et al., 2017).

\section{Таблиця 1}

Зміна щільності біоплівок тест-культур мікроорганізмів після обробки засобом “Ензидез” за різної концентрації при температурі розчинів $20 \pm 1{ }^{\circ} \mathrm{C}$ та експозиції 15 хв $(\mathrm{M} \pm \mathrm{m}, \mathrm{n}=5)$

\begin{tabular}{|c|c|c|c|}
\hline \multirow{3}{*}{ Концентрація розчинів, \% } & \multicolumn{3}{|c|}{ Тест-культури мікроорганізмів } \\
\hline & S. aureus & E. coli & P. aeruginosa \\
\hline & \multicolumn{3}{|c|}{ Оптична густина промивних розчинів з біоплівок, од } \\
\hline 1,5 & $0,12 \pm 0,01^{*}$ & $0,11 \pm 0,01 *$ & $0,10 \pm 0,01 *$ \\
\hline 1,25 & $0,13 \pm 0,01^{*}$ & $0,12 \pm 0,01 *$ & $0,11 \pm 0,01 *$ \\
\hline 1,0 & $0,15 \pm 0,01^{*}$ & $0,14 \pm 0,01 *$ & $0,14 \pm 0,01 *$ \\
\hline 0,75 & $0,19 \pm 0,01^{*}$ & $0,17 \pm 0,01 *$ & $0,17 \pm 0,01 *$ \\
\hline 0,5 & $0,24 \pm 0,01^{*}$ & $0,21 \pm 0,01 *$ & $0,20 \pm 0,01 *$ \\
\hline 0,25 & $0,32 \pm 0,02 *$ & $0,28 \pm 0,02 *$ & $0,27 \pm 0,01 *$ \\
\hline 0,1 & $0,38 \pm 0,02 *$ & $0,34 \pm 0,02 *$ & $0,32 \pm 0,02 *$ \\
\hline 0,075 & $0,73 \pm 0,03 *$ & $0,65 \pm 0,03 *$ & $0,62 \pm 0,03 *$ \\
\hline Контроль біоплівки до обробки & $1,98 \pm 0,03$ & $2,04 \pm 0,04$ & $1,97 \pm 0,03$ \\
\hline Контроль біоплівки після & & & \\
\hline обробки водою & $1,88 \pm 0,02$ & $1,93 \pm 0,02$ & $1,84 \pm 0,02$ \\
\hline Контроль МПБ & $0,10 \pm 0,01$ & $0,10 \pm 0,01$ & $0,10 \pm 0,01$ \\
\hline
\end{tabular}

Примітка: * - $\mathrm{P}<0,05$ - щодо контролю після обробки водою

3 даних табл. 1 випливає, що дезінфікуючий засіб “Ензидез” руйнує біоплівки всіх взятих у дослід музейних тест-культур мікроорганізмів. При цьому його плівкоруйнуюча активність посилювалася 3 підвищенням концентрації засобу. Зокрема, за впливу найнижчої взятої у дослід концентрації $0,075 \%$ оптична густина промивних розчинів 3 біоплівок $S$. aureus зменшилася в 2,6 раза $(\mathrm{P}<0,05)$, біоплівок E. coli i $P$. aeruginosa в 2,9 раза $(\mathrm{P}<0,05)$, відповідно, порівнюючи 3 біоплівками після обробки водою. За дії такої концентрації засобу “Ензидез" біоплівки хоч значно деградували, проте вони ще були середньої щільності, більше 0,5 од. Підвищення концентрації засобу з 0,075 \% до 0,5\% сприяло інтенсивності деградації біоплівки тест-культур, в середньому в 3,0 раза $(\mathrm{P}<0,05)$ і вони ставали слабкої щільності $(0,24-$ 0,20 од). Практично підвищення концентрації засобу "Ензидез" до 1,0 \% і більше, не суттєво руйнувало матрикс біоплівки у тест-культур мікроорганізмів, так як оптична густина промивних розчинів була як у контролі за використання чистого м'ясопептонного бульйону.
Статистичну обробку отриманих даних здійснено 3 використанням комп'ютерної програми Statistica 6.0 (StatSoft Inc., USA). Отримані дані вважали достовірними при $\mathrm{P}<0,05$.

\section{Результати досліджень}

3 метою обгрунтування і встановлення оптимальної концентрації дезінфікуючого засобу необхідно провести всебічні дослідження 3 визначення його активності за різних режимів в умовах in vitro. Тому після відбору оптимального складу засобу "Ензидез" було проведено дослідження впливу дезінфіктанту за різних концентрацій розчинів при температурі $20 \pm$ $1{ }^{\circ} \mathrm{C}$ та часу експозиції 15 хв на мікробні біоплівки тест-культур музейних мікроорганізмів. 


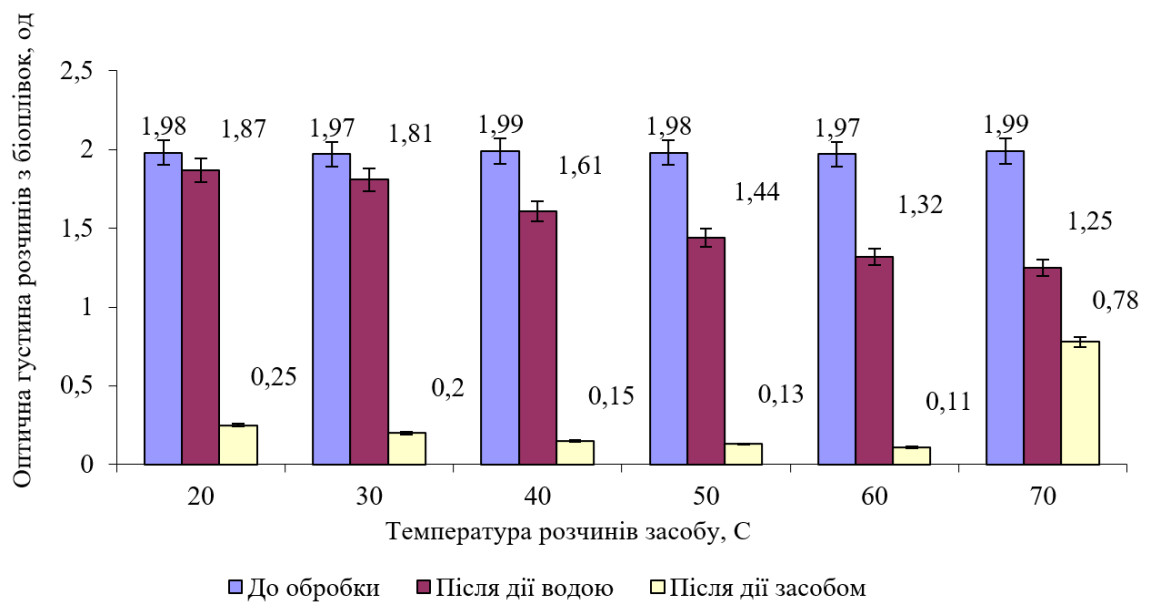

Рис. 1. Зміна щільності біоплівок золотистого стафілококу після обробки 0,5 \% засобом “Ензидез” за різних температур розчинів та експозиції 15 хв $(\mathrm{M} \pm \mathrm{m}, \mathrm{n}=5)$

3 даних рис. 1 видно, що використання робочих розчинів засобу за температури від 20 до $60^{\circ} \mathrm{C}$ сприяло деградації біоплівок золотистого стафілококу.

При цьому достовірне зменшення щільності біоплівок після обробки водою спостерігали за температури води починаючи з $50 \pm 2{ }^{\circ} \mathrm{C}$ до $70 \pm 2{ }^{\circ} \mathrm{C}$. Так після обробки біоплівок водою за температури $50 \pm 2{ }^{\circ} \mathrm{C}$ їх щільність зменшилася в 1,4 раза, а за впливу водою температури $70 \pm 2{ }^{\circ} \mathrm{C}-$ в 1,6 раза. Однак у всіх випадках після обробки водою біоплівки залишалися високої щільності більше 1,0 од.

Обробка біоплівок деззасобом “Ензидез” за температури $20 \pm 1{ }^{\circ} \mathrm{C}$ сприяла їх інтенсивній деградації, внаслідок чого оптична густина промивних розчинів 3 біоплівок зменшилася в 7,9 раза $(\mathrm{P}<0,05)$, порівнюючи 3 контролем до обробки та в 7,5 раза $(\mathrm{P}<0,05)$, порівнюючи 3 густиною розчинів після обробки водою. Підвищення температури розчинів деззасобу посилювало руйнуючий вплив на біоплівки, зокрема після впливу засобом за температури $40 \pm 1{ }^{\circ} \mathrm{C}$ оптична густина промивних розчинів 3 біоплівок зменшилася в 13,2 раза, за температури $50 \pm 2{ }^{\circ} \mathrm{C}-$ в 15,2 раза, а за $60 \pm 2{ }^{\circ} \mathrm{C}-$ в 17,9 раза $(\mathrm{P}<0,05)$, порівнюю- чи 3 густиною розчинів з біоплівок до обробки. Посилення інтенсивності руйнуючого впливу деззасобу з підвищенням температури розчинів, на нашу думку пов'язано із зростанням активності ензимів за температури розчинів від $40{ }^{\circ} \mathrm{C}$ до $60{ }^{\circ} \mathrm{C}$, а також деяким впливом температури води. Щільність біоплівок золотистого стафілококу після використання Ензидезу за даних температур не перевищувала 0,5 од і вважалася низькою.

Після обробки біоплівок Ензидезом за температури $70 \pm 2{ }^{\circ} \mathrm{C}$ спостерігали зниження його плівкоруйнуючої активності, порівнюючи з розчинами за температури $20-60{ }^{\circ} \mathrm{C}$, незважаючи на найбільший вплив води на біоплівки за температури $70{ }^{\circ} \mathrm{C}$. Це очевидно пов'язано з інгібуючим впливом температури розчину на активність ензимів наявних у засобі (Lequette et al., 2010). При цьому після обробки таким розчином деззасобу біоплівки були середньої щільності $(0,78 \pm$ 0,03 од).

Зміна щільності біоплівок кишкової палички за дії 0,5\% концентрації засобу “Ензидез” за різних температур розчинів та експозиції 15 хв наведено на рис. 2.

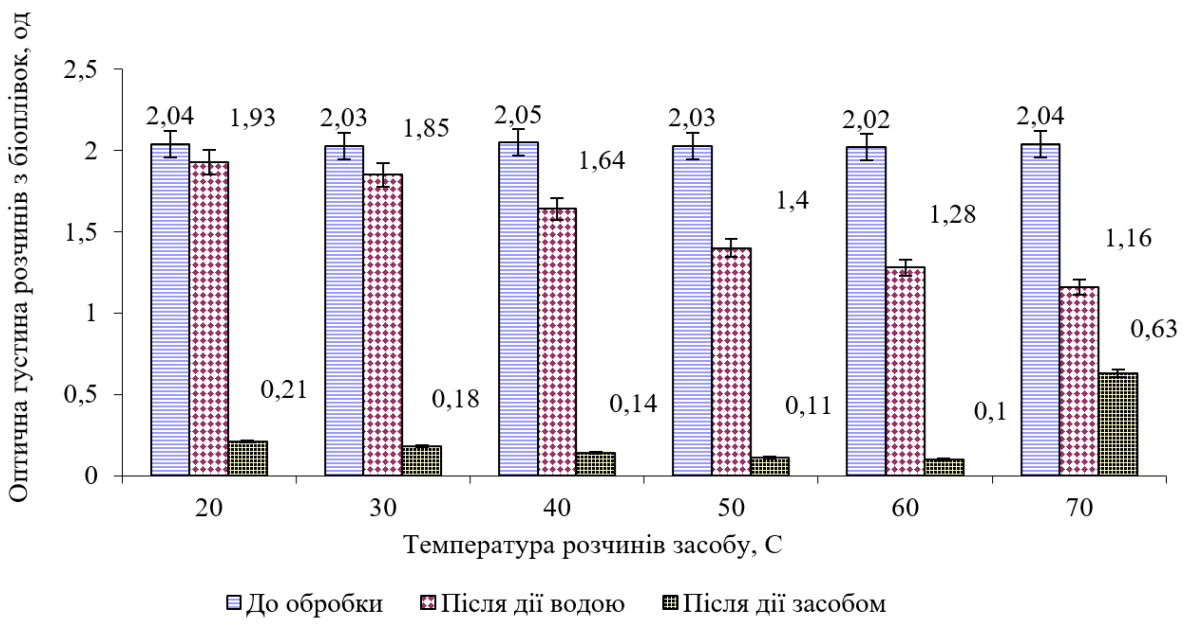

Рис. 2. Зміна щільності біоплівок кишкової палички після обробки 0,5 \% засобом “Ензидез” за різних температур розчинів та експозиції 15 хв $(\mathrm{M} \pm \mathrm{m}, \mathrm{n}=5)$ 
3 даних рис. 2 видно, що в загальному руйнування біоплівок кишкової палички після впливу деззасобу “Ензидез" за різних температур розчинів відбувалося аналогічно, як за дії на біоплівки золотистого стафілококу. Зокрема, інтенсивність деградації біоплівки найефективнішою була за температури розчинів деззасобу від $40 \pm 1{ }^{\circ} \mathrm{C}$ до $60 \pm 2{ }^{\circ} \mathrm{C}$. За впливу Ензидезу за даних температур зменшення оптичної густини розчинів з біоплівок відбулося в 14,6 - 18,4 раза $(\mathrm{P}<0,05)$, проти контролю до обробки. При цьому оптична густина розчинів 3 біоплівок становила від 0,14 до 0,1 од, що відносить їх до слабкої щільності.
Найменша деградація біоплівок спостерігалася за дії деззасобу температура розчину, якого становила $70 \pm 2{ }^{\circ} \mathrm{C}$. Руйнування біоплівок за цієї температури в більшій мірі відбувається під впливом температурної денатурації, ніж під впливом ензимів і дезінфікуючих компонентів. Після обробки біоплівки залишалися зазвичай середньої щільності - $0,63 \pm 0,03$ од.

Зміна щільності біоплівок синьогнійної палички за дії 0,5 \% концентрації засобу "Ензидез" за різних температур розчинів та експозиції 15 хв наведено на рис. 3.

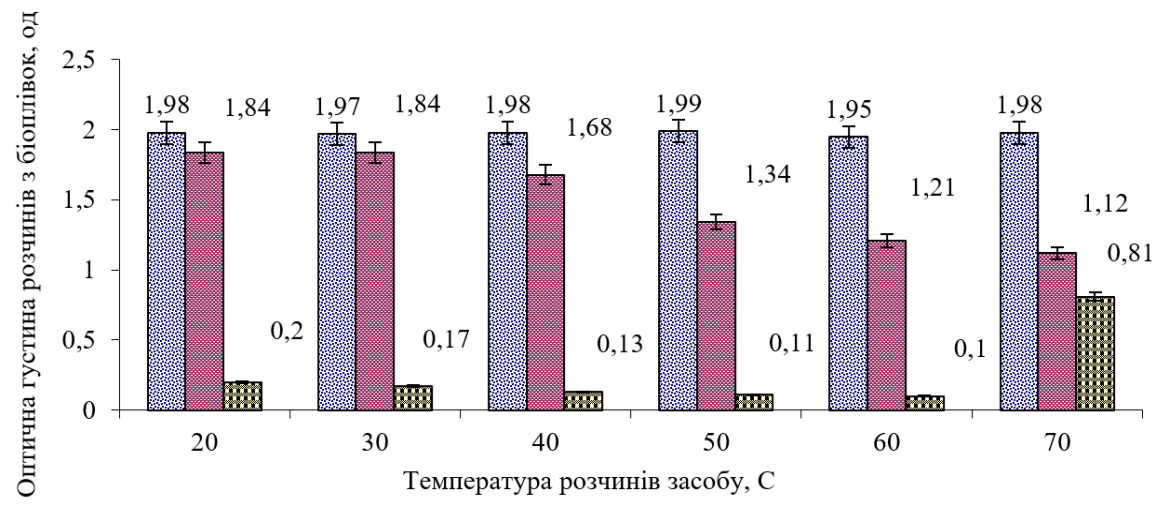

圈 До обробки 圈 Після дії водою

Рис. 3. Зміна щільності біоплівок синьогнійної палички після обробки 0,5 \% засобом “Ензидез” за різних температур розчинів та експозиції 15 хв (M $\pm \mathrm{m}, \mathrm{n}=5)$

Результати досліджень рис. 3 виявили, що під впливом засобу "Ензидез” біоплівки синьогнійної палички добре деградували за всіх температур розчинів. При цьому за дії засобу в температурному режимі розчинів від 20 до $60{ }^{\circ} \mathrm{C}$ щільність усіх біоплівок не перевищувала $0,20 \pm 0,02$ од. Винятком слугувала температура розчину засобу $70 \pm 2{ }^{\circ} \mathrm{C}$, за якої деградація біоплівки відбувалася слабо, так як оптична густина розчину з біоплівок становила $0,81 \pm 0,03$ од. За обробки засобом за даної температури щільність біоплівок була всього в 1,4 раза менша, ніж за обробки водою даної температури. Це підтверджує наявність в більшій мірі дії температури, ніж самого засобу. Крім того, така слабка активність біоциду вказує на те, що використання засобу за високої температури робить його слабоактивним.

Отже, підсумовуючи дані дослідження можна відзначити, що із підвищенням температури дезінфікуючого засобу "Ензидез" з +20 до +60 C відбувається збільшення деградації біоплівок сформованих золотистим стафілококом, кишковою і синьогнійною паличками. При цьому з отриманих даних випливає, що деззасіб можна ефективно використовувати в $0,5 \%$ концентрації за кімнатної температури розчинів. Дані результати було застосовано у подальших дослідженнях з обгрунтуванням оптимального часу експозиції.

Крім вибору найефективнішої концентрації і температури дезінфікуючого засобу, дослідження з ви- значення оптимального часу експозиції являються одними із пріоритетними. Так як, правильно підібрана експозиція дезінфікуючого засобу є важливою складовою бактерицидної активності та в подальшому розробки ефективного режиму його застосування. Результати досліджень 3 визначення зміни щільності біоплівок золотистого стафілококу після обробки 0,5 \% розчином засобу “Ензидез” за температури $20 \pm$ $1{ }^{\circ} \mathrm{C}$ та різного часу експозиції наведено на рис. 4.

Дані рис. 4 вказують, на наявність прямо залежного ефекту щодо інтенсивності зниження щільності біоплівок золотистого стафілококу від тривалості часу експозиції дезінфікуючого засобу. Зокрема, після 5 хв дії деззасобу "Ензидез” оптична густина розчинів 3 біоплівок знизилася до $0,44 \pm 0,03$ од., а через 15 хв експозиції вона була в 1,8 раза $(\mathrm{P}<0,05)$ менша $(0,24 \pm 0,02$ од), ніж за п'яти хвилинної дії. Загалом для видалення біоплівок золотистого стафілококу 0,5\% засобом “Ензидез” за температури розчинів $+20 \pm 1{ }^{\circ} \mathrm{C}$ необхідно, щоб час експозиції становив від 15 до 30 хв. Протягом даного періоду дії деззасобу оптична густина розчинів з біоплівок зменшувалася до 0,24-0,13 од, що вважається, як слабкої щільності біоплівки.

Динаміка зміни щільності біоплівок кишкової палички після обробки 0,5 \% розчином засобу “Ензидез” за температури $20 \pm 1{ }^{\circ} \mathrm{C}$ та різного часу експозиції наведена на рис. 5. 


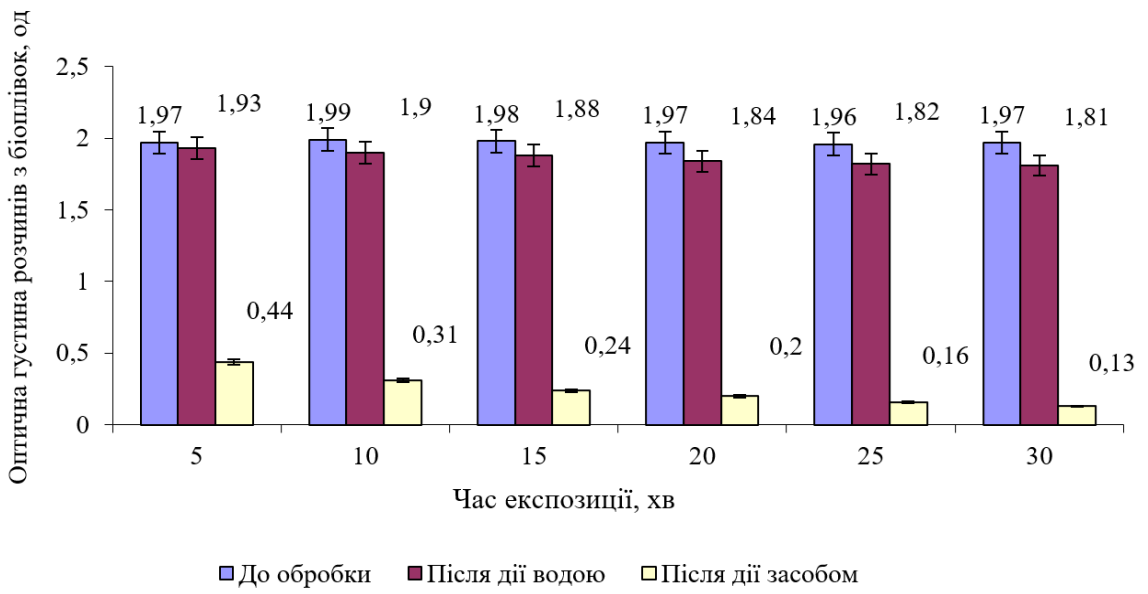

Рис. 4. Зміна щільності біоплівок золотистого стафілококу після обробки 0,5 \% розчином засобу “Ензидез” за температури $20 \pm 1{ }^{\circ} \mathrm{C}$ та різного часу експозиції $(\mathrm{M} \pm \mathrm{m}, \mathrm{n}=5)$

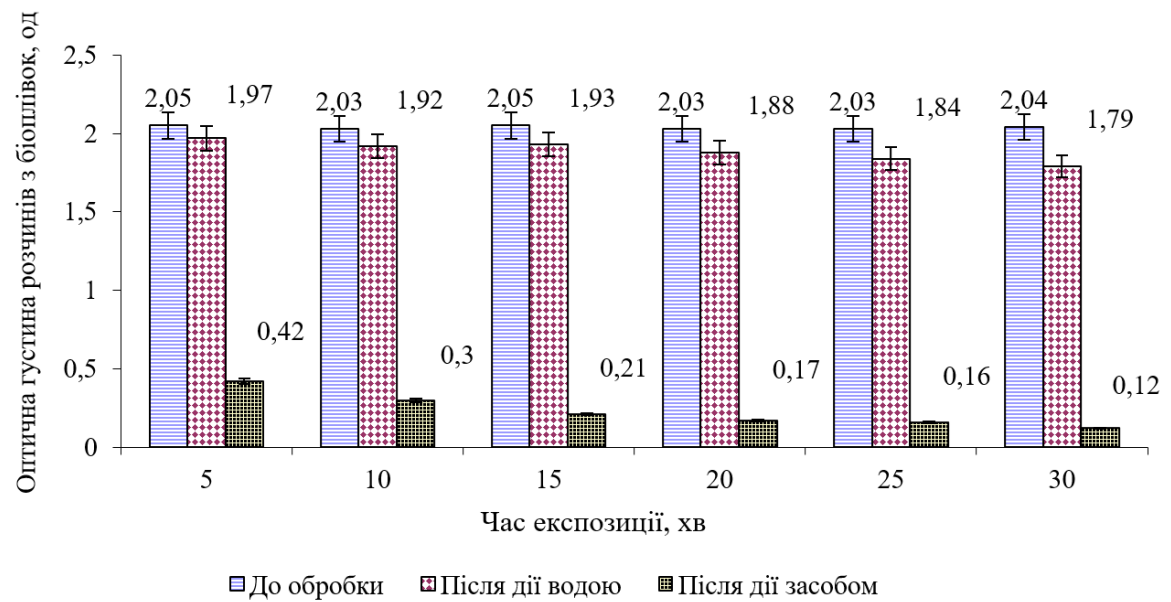

Рис. 5. Зміна щільності біоплівок кишкової палички після обробки 0,5 \% розчином засобу “Ензидез" за температури $20 \pm 1^{\circ} \mathrm{C}$ та різного часу експозиції $(\mathrm{M} \pm \mathrm{m}, \mathrm{n}=5)$

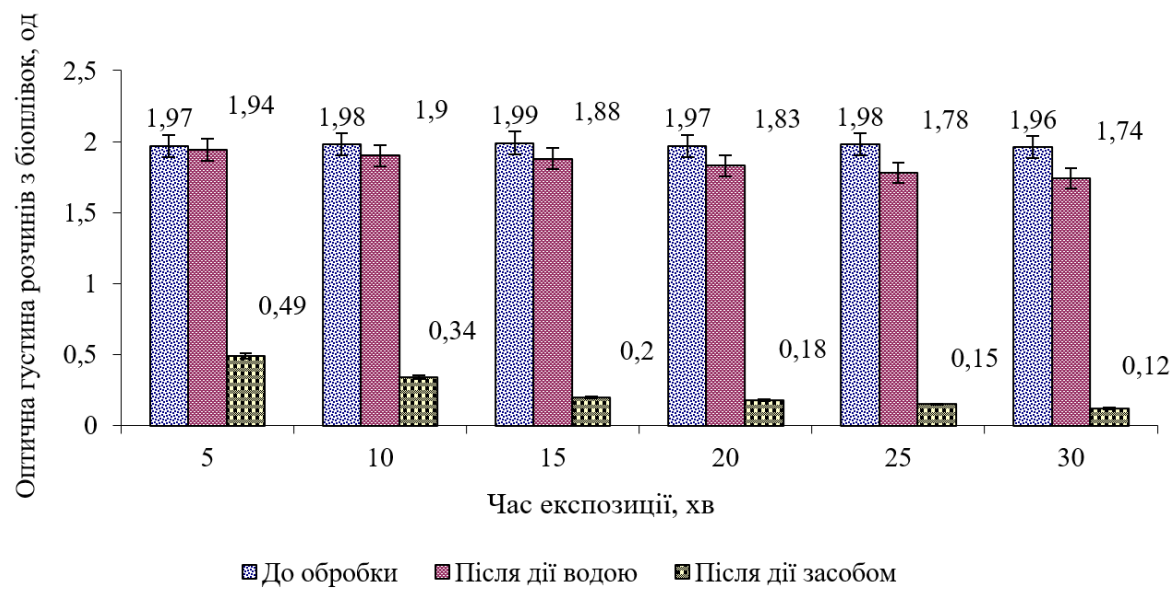

Рис. 6. Зміна щільності біоплівок синьогнійної палички після обробки 0,5 \% розчином засобу “Ензидез” за температури $20 \pm 1{ }^{\circ} \mathrm{C}$ та різного часу експозиції $(\mathrm{M} \pm \mathrm{m}, \mathrm{n}=5)$

3 даних рис. 5 видно, що навіть за п’ятихвилинної дії деззасобом "Ензидез" спостерігається суттєва деградація біоплівок, так як оптична густина розчинів 3 біоплівок зменшилася в 4,7 раза $(\mathrm{P}<0,05)$ до $0,42 \pm 0,03$ од, порівняно 3 обробкою водою протягом даного часу. Наступне подовження експозиції дезза- собу до 15 хв сприяло зменшенню щільності біоплівок в 2,0 раза $(\mathrm{P}<0,05)$ до $0,21 \pm 0,02$ од, проти 5 хв діï. За часу експозиції деззасобу від 15 до 30 хв відбулася практично повністю деградація біоплівок кишкової палички з поверхні пластин нержавіючої сталі. 
Аналогічні зміни відбувалися щодо процесу деградації біоплівок сформованих синьогнійною паличкою за впливу деззасобу “Ензидез” (рис. 6). Зокрема, протягом 15-30 хв експозиції 0,5 \% розчину засобу “Ензидез" за температури $+20 \pm 1{ }^{\circ} \mathrm{C}$ видаляється в повній мірі біоплівка, що вказує на недоцільність збільшення часу експозиції більше 30 хв.

\section{Обговорення}

Наявність мікробних біоплівок на поверхнях медичних інструментів, операційному обладнанні, протезах, катетерах, технологічних лініях у харчовій промисловості вважається чинником, який сприяє інфікуванню макроорганізму, забрудненню сировини та продукції (Hoque et al., 2015; Kukhtyn et al., 2017; Berhilevych et al., 2017). Тому використання біоцидів направлене на знищення планктонних і біоплівкових форм мікроорганізмів на різних поверхнях (Augustin et al., 2004; Kovalenko et al., 2018; Palii et al., 2020). Однак успішна боротьба з мікроорганізмами, які перебувають у біоплівках, можлива за умови застосування дезінфікуючих засобів, які руйнують екзополісахаридний матрикс і сприяють тіснішому контакту бактерій з біоцидом (Lequette et al., 2010). У даному досліджені нами визначено активність дезіфікуючого засобу "Ензидез" щодо впливу на мікробні біоплівки в умовах in vitro за різних параметрів засосування. Виявлено, що дезінфікуючий засіб “Ензидез” руйнує біоплівки взятих у дослід музейних тест-культур S. aureus, E. coli i P. aeruginosa.

Зокрема, за впливу найнижчої взятої у дослід концентрації 0,075 \% оптична густина промивних розчинів з біоплівок $S$. aureus зменшилася в 2,6 раза, біоплівок E. coli i P. aeruginosa в 2,9 раза, відповідно, порівнюючи з біоплівками після обробки водою. За дії такої концентрації засобу “Ензидез” біоплівки хоч значно деградували, проте вони ще були середньої щільності, більше 0,5 од. Підвищення концентрації засобу з 0,075 \% до 0,5\% сприяло інтенсивності деградації біоплівки тест-культур, в середньому в 3,0 раза $(\mathrm{P}<0,05)$ і вони ставали слабкої щільності $(0,24-$ 0,20 од). Підвищення концентрації засобу "Ензидез" до 1,0 \% і більше, не суттєво руйнувало матрикс біоплівки мікроорганізмів, так як оптична густина промивних розчинів була як у контролі. Це вказує на те, що додавання у склад засобу ензимів різних класів $є$ доброю перспективою для руйнування мікробних біоплівок та деградації органічних компонентів із поверхні. Про необхідність розробки деззасобів, які впливають на бактерії у біоплівках повідомляють чисельні дослідження (Kukhtyn et al., 2019; Kovalenko et al., 2020). Це пов'язано $з$ тим, що концентрація робочого розчину біоциду необхідна для знищення бактерій у біоплівках в декілька десятків разів вища за ту, яка діє бактерицидно на планктонні форми бактерій (DavinRegli et al., 2012; Abdallah et al., 2014; Kukhtyn et al., 2017; Horiuk et al., 2019).

При визначенні впливу температури робочих розчинів засобу “Ензидез” на його плівкоруйнуючу активність, встановлено, що із підвищенням температури дезінфікуючого засобу “Ензидез” з +20 до $+60{ }^{\circ} \mathrm{C}$ відбувається збільшення деградації біоплівок сформованих золотистим стафілококом, кишковою і синьогнійною паличками. При цьому з отриманих даних випливає, що деззасіб можна ефективно використовувати в 0,5 \% концентрації за кімнатної температури розчинів. Отримані результати узгоджуються 3 даними (Salata et al., 2018), які повідомляють, що лужний мийно-дезінфікуючий засіб “Санактив” у 0,5 \% концентрації та за температури розчинів $65 \pm 2{ }^{\circ} \mathrm{C}$ інгібував бактерії $S$. aureus, E. faecalis у біоплівці протягом 10 хв діï, a E. coli $i$ P. aeruginosa протягом 30 хв впливу. Також, повідомляється що засіб “Мілкодез” знижував щільність біоплівок до низької у S. aureus, E. coli $i$ P. aeruginosa після 15 хв експозиції за температури $70^{\circ} \mathrm{C}$ (Verkholyuk et al., 2020).

При обгрунтуванні часу експозиції деззасобу “Ензидез” виявлено, що для видалення біоплівок S. aureus, E. coli i P. aeruginosa $0,5 \%$ засобом за температури розчинів $+20 \pm 1{ }^{\circ} \mathrm{C}$ необхідно, щоб час дії становив від 15 до 30 хв. Протягом даного періоду дії деззасобу оптична густина розчинів з біоплівок зменшувалася до 0,24-0,13 од, що вважається, як слабкої щільності біоплівки. Тобто спостерігається чітко виражений синергізм ензимів і дезінфікуючої субстанції, що в кінцевому етапі більш згубно діє на бактерії у біоплівках. У даному випадку можна стверджувати, що ензими руйнують матрикс біоплівки, що сприяє кращому контакту антибактеріальних речовини 3 клітинами-мішенями.

Отже, дані дослідження вказують, що ефективний, оптимальний час дії дезінфікуючого засобу "Ензидез” на біоплівки сформовані S. aureus, E. coli і P. aeruginosa становить $15-30$ хв.

\section{Висновки}

Дезінфікуючий засіб “Ензидез” проявляє добру ефективність щодо руйнування мікробних біоплівок S. aureus, E. coli i $P$. aeruginosa у концентрації 0,5\% за температури розчинів $+20 \pm 1{ }^{\circ} \mathrm{C}$ та експозиції $15-$ 30 хв. Це дає підставу проведення подальших досліджень 3 визначення його ефективності у виробничих умовах.

Відомості про конфлікт інтересів. Автори стверджують про відсутність конфлікту інтересів щодо їх вкладу та результатів досліджень.

\section{References}

Abdallah, M., Benoliel, C., Drider, D., Dhulster, P., \& Chihib, N-E. (2014). Biofilm formation and persistence on abiotic surfaces in the context of food and medical environments. Arch. Microbiol., 196(7), 453472 doi: 10.1007/s00203-014- 0983-1.

Augustin, M., Ali-Vehmas, T., \& Atroshi, F. (2004). Assessment of enzymatic cleaning agents and disinfectants against bacterial biofilms. Journal of pharmacy and pharmaceutical science, 7(1), 55-64. URL: https://pubmed.ncbi.nlm.nih.gov/15144735. 
Berhilevych, O. M., Kasianchuk, V. V., Kukhtyn, M. D., Lotskin, I. M., Garkavenko, T. O., \& Shubin P. A. (2017). Characteristics of antibiotic sensitivity of Staphylococcus aureus isolated from dairy farms in Ukraine. Regulatory Mechanisms in Biosystems, 8(4), 559-563. doi: 10.15421/021786.

Costerton, J. W., Veeh, R., \& Shirliff, M. (2003). The application of biofilm science to the study and control of chronic bacterial infections. J. Clin. Invest., 112(10), 1466-1477. doi: 10.1172/JCI20365.

Davin-Regli, A., \& Pagès, J.-M. (2012). Cross-resistance between biocides and antimicrobials: an emerging question. Revue Scientifique et Technique, 31(1), 89104. doi: 10.20506/RST.31.1.2099.

Hoque, J., Konai, M. M., Gonuguntla, S., Manjunath, G., B., Samaddar, S., Yarlagadda, V., \& Haldar, J. (2015). Membrane Active Small Molecules Show Selective Broad Spectrum Antibacterial Activity with No Detectable Resistance and Eradicate Biofilms. J. Med. Chem., 58(14), 5486-5500. doi: 10.1021/ acs.jmedchem.5b00443.

Horiuk, Yu., Kukhtyn, M., Kovalenko, V., Kornienko, L.. Horiuk, V., \& Liniichuk N. (2019). Biofilm formation in bovine mastitis pathogens and the effect on them of antimicrobial drugs. Independent journal of management and production (IJM\&P), 7(10), 897-910. doi: 10.14807/ijmp.v10i7.1012.

Kovalenko, A. M., Tkachev, A. V., Tkacheva, O. L., Gutyj, B. V., Prystupa, O. I., Kukhtyn, M. D., Dutka, V. R., Veres, Ye. M., Dashkovskyy, O. O., Senechyn, V. V., Riy, M. B., \& Kotelevych, V. A. (2020). Analgesic effectiveness of new nanosilver drug. Ukrainian Journal of Ecology, 10(1), 300-306. doi: $10.15421 / 202047$

Kovalenko. V. L., Kovalenko, P. L., Ponomarenko, G. V., Kukhtyn, M. D., Midyk, S. V., Horiuk, Yu. V., \& Garkavenko, V. M. (2018). Changes in lipid composition of Escherichia coli and Staphylococcus areus cells under the influence of disinfectants Barez, Biochlor and Geocide. Ukrainian Journal of Ecology, 8(1), 547-550. doi: 10.15421/2018 248 .
Kukhtyn, M., Berhilevych, O., Kravcheniuk, K., Shynkaruk, O., Horiuk, Y., \& Semaniuk, N. (2017). Formation of biofilms on dairy equipment and the influence of disinfectants on them. Eastern-European journal of Enterprise Technologies, 5/11, 89, 26-33. doi: 10.15587/1729-4061.2017.110488.

Kukhtyn, M., Kravcheniuk, K., Beyko, L., Horiuk, Y., Skliar, O., \& Kernychnyi, S. (2019). Modeling the process of microbial biofilm formation on stainless steel with a different surface roughness. Eastern-European journal of Enterprise Technologies, 2/11(98), 14-21. doi: 10.15587/1729-4061.2019.160142.

Kukhtyn, M. D., Kovalenko, V. L., Garkavenko, V. M., Gorbatyuk, O. I., Kozytska, T. G., Boltyk, N. P., Klimik, V. T., Rushchinskaya, T. M., Horiuk, Y. V., \& Salata, V. Z. (2020). Metodychni rekomendatsiyi z vyznachennya bakterytsydnoyi aktyvnosti dezinfikuyuchykh zasobiv na bakteriyakh u bioplivkakh. Metodychni rekomendatsii. Kiev (in Ukrainian).

Lequette, Y., Boels, G., Clarisse, M., \& Faille, C. (2010). Using enzymes to remove biofilms of bacterial isolates sampled in the food-industry. Biofouling, 26(4), 421-431. doi: 10.1080/08927011003699535.

Palii, A. P., Kovalenko, V. L., Ponomarenko, G. V., Kukhtyn, M. D., Paliy, A. P., Bodnar, O. O., Rebenko, H. I., Kozytska, T. G., Makarevich, T. V., \& Ponomarenko, O. V. (2020). Evaluation of acute toxicity of the "Orgasept" disinfectant. Ukrainian Journal of Ecology, 10(4), 273-278. doi: 10.15421/2020_199.

Salata, V., Kukhtyn, M., Pekriy, Yu., Horiuk, Yu., \& Horiuk, V. (2018). Activity of washing-disinfecting means "San-active" for sanitary treatment of equipment of meat processing enterprises in laboratory and manufacturing conditions. Ukrainian journal of veterinary and agricultural sciences, 1(1), 10-16. doi: 10.15421/ujvas1-1.02.

Verkholyuk, M., Peleno, R., \& Turko. I. (2020). Resistance of S. Aureus Atcc 25923, E. Coli 055k59 No. 3912/41 and P. Aeruginosa 27/99 to the Washdisinfectant "Milkodez". EUREKA: Health Sciences, 1, 55-60. doi: 10.21303/2504-5679.2020.001100. 